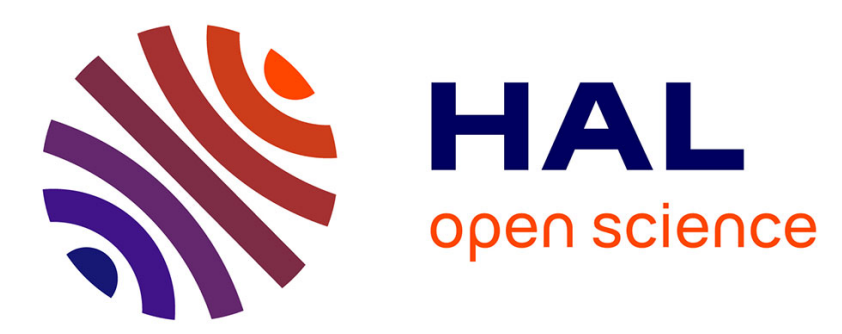

\title{
Therapeutic potential of group III metabotropic glutamate receptor ligands in pain
}

Francine Acher, Cyril Goudet

\section{To cite this version:}

Francine Acher, Cyril Goudet. Therapeutic potential of group III metabotropic glutamate receptor ligands in pain. Current Opinion in Pharmacology, 2015, 20, pp.64-72. 10.1016/j.coph.2014.11.007 . hal-01950127

\author{
HAL Id: hal-01950127 \\ https://hal.umontpellier.fr/hal-01950127
}

Submitted on 13 Feb 2020

HAL is a multi-disciplinary open access archive for the deposit and dissemination of scientific research documents, whether they are published or not. The documents may come from teaching and research institutions in France or abroad, or from public or private research centers.
L'archive ouverte pluridisciplinaire HAL, est destinée au dépôt et à la diffusion de documents scientifiques de niveau recherche, publiés ou non, émanant des établissements d'enseignement et de recherche français ou étrangers, des laboratoires publics ou privés. 


\title{
Therapeutic potential of group III metabotropic glutamate receptor ligands in pain
}

\author{
Francine Acher ${ }^{1}$ and Cyril Goudet ${ }^{2,3}$
}

${ }^{1}$ Laboratoire de Chimie et Biochimie Pharmacologiques et Toxicologiques, CNRS UMR8601,

Université Paris Descartes, Sorbonne Paris Cité, Paris, France

${ }^{2}$ Institut de Génomique Fonctionnelle, CNRS UMR5203, Université de Montpellier, Montpellier, France

${ }^{3}$ INSERM, U661, Montpellier, France

\section{Corresponding authors:}

Francine Acher

Laboratoire de Chimie et Biochimie Pharmacologiques et Toxicologiques, CNRS UMR8601, Université Paris Descartes, Sorbonne Paris Cité, Paris, France. 45, Rue des Saints-Pères, F75270 Paris cedex.

francine.acher@parisdescartes.fr

Cyril Goudet

Institut de Génomique Fonctionnelle, 141 rue de la cardonille, F34094 Montpellier cedex 5

cyril.goudet@igf.cnrs.fr 


\section{ABSTRACT}

Metabotropic glutamate receptors (mGluRs) modulate neurotransmission all along the pain neuraxis. While the involvement of group I and group II mGluRs in pain is well documented, information has only just started to emerge concerning the role and contribution of group III mGluRs subtypes to pain modulation. Recent data suggests that these receptors reduce symptoms in animal models of chronic pain, as well as regulate neurotransmission at different levels of ascending and descending pain pathway, suggesting that group III mGluRs may be interesting therapeutic targets for the development of analgesics. 


\section{INTRODUCTION}

Pain is one of the most common symptoms in clinical medicine and represents a permanent medical problem, being an essential component in the therapeutic management of many diseases. Pain can be classified as acute when it is short lasting or chronic when it persists for a long time after the original affection. Acute pain serves the important function of protecting the integrity of the body by detecting actual or potential tissue damage. Chronic pain is among the most debilitating and costly afflictions in North America and Europe, seriously affecting the quality of life of more than $19 \%$ of adult Europeans [1-3]. Unfortunately, while acute pain can be correctly managed, chronic pain is not efficiently alleviated by current treatments [4-6]. Therefore, a better understanding of cellular and molecular pathophysiological mechanisms is essential for identifying new pharmacological targets.

\section{Glutamate and pain}

Glutamate is the main excitatory neurotransmitter of the mammalian central nervous system and is implicated in many physiological and pathological processes. Glutamate is notably the main neurotransmitter involved in pain transmission. At the synaptic level, glutamate activates two classes of receptors: ionotropic and metabotropic glutamate receptors (mGluRs). Central sensitization of the pain neuraxis is associated with hyperexcitability of the glutamatergic system and leads to the development of the evoked pain symptoms, allodynia (pain due to a stimulus that does not normally provoke pain) and hyperalgesia (increased pain from a stimulus that normally provokes pain) observed in patients with chronic pain [7]. Both iGluRs and mGluRs are involved in the induction and the maintenance of this sensitization. The blockade of increased glutamatergic activity may represent a pivotal mean to reduce chronic pain but awaits a clearer identification of adequate targets.

\section{Metabotropic glutamate receptors}

mGluRs are G-protein coupled receptors activated by glutamate, the major excitatory neurotransmitter of the central nervous system (CNS). They are involved in the modulation of synaptic activity. They are thus considered as potential therapeutic targets since less side effects are anticipated compared to essential actors of synaptic transmission.

The 8 members of this family are classified in 3 groups: Group I receptors (mGlu1 and 5) are postsynaptic and positively modulate glutamatergic transmission while group II ( $\mathrm{mGlu2}$ and 3 ) and group III receptors (mGlu4, 6, 7 and 8) are predominantly presynaptic and play an inhibitory role on neurotransmission (except for mGlu6, a post-synaptic receptor which is expressed solely in bipolar ON cells in the retina). Group III mGluRs can act either as autoreceptors on glutamatergic terminals or heteroreceptors on GABAergic terminals. 
mGluRs form constitutive dimers composed of two subunits cross-linked by a disulphide bridge. Dimer formation is mandatory for the function of these receptors [8]. It has long been believed that mGluRs strictly assemble into homodimers but a recent study has shown that certain mGluR subtypes can heterodimerize in vitro [9]. Heterodimerization could have consequences notably in terms of pharmacological profile, signalling response and protein partners. To date, there is no clear evidence of heterodimerization of mGluRs in vivo. However, recently, mGlu2/4 heterodimers have been suspected of existing at corticostriatal synapses, based on the detection of a unique pharmacological profile as compared to the mGlu2 or mGlu4 homodimers [10]. Since compatible mGluR subtypes coexist in several regions of the CNS, our comprehension of the regulation of CNS function by mGluRs, including pain, may evolve rapidly in the light of heterodimerization.

The different subtypes of mGluRs are expressed all along the pain neuraxis where they modulate the perception of pain (Figure 1). In general, blocking group-I mGluRs or activating group-II mGluRs alleviates pain (see [11-13] for recent reviews).

The present review will focus on group III mGluRs for which less information is available, mainly due to the lack of selective pharmacological tools. However, the recent progress in the development of subtype selective ligands are opening the way to a better understanding of their modulatory function and therapeutic potential in pain.

\section{GROUP III MGLUR PHARMACOLOGY}

As described in Figure 1, mGlu4, 7, 8 receptors of group III are localized all along the pain neuraxis. In order to investigate if these receptors may be novel therapeutic targets to reduce pain symptoms, various ligands were used (Figure 2). However, interpretation of these experiments should take into consideration the limitations of these compounds. Most of the drugs that were evaluated are nonselective among the group III subtypes or display metabolic instability. Moreover, a 100 ratio of EC50's in cell-based assays does not ensure a selective effect in vivo since other factors such as bioavailability, receptor localization and drug concentration may also have an influence.

Both orthosteric ligands and allosteric modulators have been employed. These ligands are listed in this chapter, together with their effects and, when known, their limitations.

\section{Orthosteric ligands}

Since mGlu4, 7, 8 receptors are mostly presynaptic, agonists were used to evaluate if downregulation of neurotransmitter release mediated by their activation may provide any benefit to treat 
pain symptoms (Figure 2). The most widely applied drug is L-AP4, a selective agonist of group III mGlu receptors, which does not discriminate between mGlu4 and 8 receptors, that has been used in inflammatory and neuropathic pain models [14-24]. L-AP4 is about 10 times more potent than glutamate, however, it does not cross the blood brain barrier and needs to be injected in situ. L-SOP, a phosphate analog of L-AP4 with similar properties, has been used in early studies about the contribution of group III mGluRs in the periaqueductal gray to the regulation of nociception $[25,26]$. ACPT-I is a group III mGluR agonist demonstrating similar selectivity to L-AP4 but is able to be administered systemically $[27,28]$. The use of ACPT-I [27] provided successful results in rat models of inflammatory and neuropathic pain, while leaving acute pain perception unchanged in healthy rats [29]. The weaker agonist, ACPT-III, was also used and shown to enhance the antiallodynic action of morphine in a neuropathic pain model in rats [30]. Two compounds (S)-DCPG [31] and LSP4-2022 [32] have been tested as mGlu8 and mGlu4 receptor subtype selective agonists, respectively, in inflammatory or neuropathic pain models [23,33-37]. However, a recent study suggests that care must be taken when employing higher concentrations of DCPG since non-selective effects in slices from mice lacking mGlu8 receptors have been observed with DCPG concentrations above $1 \mu \mathrm{M}$, primarily mediated by mGlu2 receptors [38].

Competitive group III mGlu receptor antagonists have been used to assess the validity of agonist effects but also to verify the interaction between glutamatergic and GABAergic synapses in the spinal dorsal horn after stimulation of the nociceptive primary afferents [39]. The most potent group III antagonist is LY341495, however, it is even more potent at group II mGlu receptors [40]. Nevertheless, it has been used in several studies $[17,18,20,22,29,39,41]$. Other antagonists, such as MAP4, MSOP and CPPG, are more specific to group III but are weaker. Yet they were still useful tools in most pain studies (MAP4 [16,29,35,41,42], MSOP[20,23,25,34,43-46], CPPG [17-19,39])

\section{Allosteric modulators}

Positive allosteric modulators (PAMs) have been assayed for pain relief (Figure 2). PHCCC, the first identified mGlu4 selective PAM $[47,48]$, revealed similar effects to ACPT-I in inflammatory or neuropathic pain models [29]. Another mGlu4 PAM, VU155041 [49], attenuated mechanical hyperalgesia in a neuropathic pain rat model when injected intrathecally [54], but was ineffective in changing thermal nociception and ON and OFF cell activity when injected in the dorsal striatum of naive or neuropathic rats [37]. The discovery of new mGlu4 receptor PAMs [50] should allow further investigations. An mGlu8 receptor PAM, AZ12216052 [51], behaved like (S)-DCPG, the orthosteric agonist with similar selectivity, increasing tail flick latency and OFF cell activity and decreasing ON cell activity in neuropathic rats after injection into the dorsal striatum [37]. However, AZ12216052 
reduced anxiety in mGlu8 KO mice, suggesting that this PAM may also act on other receptors mGlu8 [52]. The mGlu7 agonist-PAM AMN082 [53] has attracted much interest and was introduced in the largest evaluation of group-III PAMs' [21,23,33-35,46,54,55]. However, contradictory results were described and should be taken with precaution as AMN082 is rapidly metabolized into a monoamine transporter inhibitor [56]. A negative allosteric modulator (NAM) of mGlu7 receptor, MMPIP [57], was recently used in series of experiments, showing the antinociceptive effect of the blockade of this particular receptor in the ventrolateral periaqueductal gray in formalin and neuropathic pain models [58]. Interestingly, the inhibiting activity of MMPIP has been reported to be context dependent, meaning that MMPIP may not antagonize the coupling of mGlu7 to its native signaling pathways in all cellular contexts, as exemplified by its inability to block agonist-mediated responses at the Schaffer collateral-CA1 synapse, where mGlu7 has been previously shown to modulate neurotransmission [59]. This context-dependent signaling bias has to be taken into consideration when using this compound and its derivatives. In addition, the new mGlu7 NAM's ADX71743 [60] and XAP044 [61] should allow future investigations.

\section{PHENOTYPES OF GROUP III MGLURS KNOCK-OUT MICE}

Mice lacking mGlu4 receptors display normal spontaneous motor activity but present an impaired ability to learn and memorize $[62,63]$. The sensitivity to strong noxious mechanical compression is altered and the onset of the nociceptive behavior in the inflammatory phase of the formalin test is accelerated in mGlu4 KO mice as compared to their wild type littermates, whereas responses to punctate mechanical stimulation and nocifensive responses to thermal noxious stimuli are not modified [36]. To our knowledge, the sensory perception phenotypes of mGlu7 and mGlu8 KO mice have not been determined. Mice lacking mGlu7 present increased seizure susceptibility [64] together with an antidepressant and anxiolytic-like phenotype [65] while mGlu8 KO mice exhibit an anxiogenic phenotype $[51,66,67]$. Interestingly, subtle differences in amygdala-dependent behavior and physiology between mGlu7 and mGlu8 KO mice suggest differential roles of these receptors. Indeed, while mGlu7 KO mice display a general deficit in conditioned fear, mGlu8 KO mice show a dramatic reduction in contextual fear [68]. These results are well correlated with studies that used a pharmacological approach (see below). Since there is a strong comorbidity between chronic pain, depression and anxiety [4], targeting these receptors may be of interest in chronic pain.

\section{LOCALIZATION AND ROLE OF GROUP III MGLURS IN THE PAIN NEURAXIS}


The presence of group III mGluRs has been identified in different areas involved in pain processing (Figure 1), with the exception of mGlu6 which is exclusively expressed in the retina.

\section{Periphery}

Few studies have addressed the role of peripheral group III mGluRs in pain. Intraplantar group III mGluR agonist L-AP4 delivery attenuates the increased nociception induced by capsaicin $[22,69]$ or bee venom [20], while administration of L-AP4 into the knee joint reduces hyperalgesia induced by carrageenan-induced arthritic pain [24]. mGlu8 has been identified in the unmyelinated axons of digital nerves [69]. To our knowledge, the expression of other subtypes of group III mGluRs that may also mediate L-AP4 action in the periphery has not been documented.

\section{Spinal cord}

The superficial laminae of the dorsal horn of the spinal cord receives sensory information from primary afferents responding to noxious and non-noxious stimuli (see [70] for a comprehensive review on pain processing in the dorsal horn). mGlu4 is present in the inner lamina II of the dorsal horn of spinal cord [71-73], more precisely, both in the presynaptic terminal of unmyelinated C-fibers and spinal neurons terminals [36]. mGlu7 is located in presynaptic terminal of sensory neurons in the laminae I and II in the dorsal horn [73] but the nature of sensory neurons expressing mGlu7 remains to be determined. mGlu8 is located in the soma of TRPV1 expressing-unmyelinated DRG neurons $[69,74]$, but doesn't seem to be present in the spinal cord $[75,76]$.

Interestingly, spinal group III mGluRs, and mGlu4 in particular, seem to be devoted to the modulation of hypersensitivity to applied stimuli observed in animal models of persistent or chronic pain, whilst leaving reactions to acute noxious stimuli unchanged in naive animals. Indeed, spinal group III mGluR activation by intrathecal injection of selective group III agonists (L-AP4 or ACPT-I) reduces hypersensitivity to pain in animal models of inflammatory or neuropathic pain without affecting acute pain perception in healthy animals $[15,16,29,77]$. Moreover, activation of spinal group III mGluRs decreases firing of spinal cord dorsal horn projection neurons [16] and their ability to control the excess of excitatory transmission is reinforced in spinal cord of inflamed or neuropathic animals $[19,36]$.

Similar effects are obtained by the selective activation of spinal mGlu4. Indeed, intrathecal application of the selective mGlu4 agonist LSP4-2022 [36], or the selective mGlu4 PAMs PHCCC [29] and VU0155041 [55], alleviates pain hypersensitivity in animal models of chronic pain without 
affecting acute pain in healthy animals. Interestingly, the systemic injection of mGlu4 agonist LSP42022 abolishes mechanical hypersensitivity in inflammation [36]. On the other hand, intrathecal administration of AMN082, an mGlu7 PAM, does not reduce hyperalgesia in neuropathic pain [55].

\section{Supraspinal}

At the supraspinal level, the various subtypes of group III mGluRs can be found in the different areas of the pain ascending and descending pathways (Figure 1).

The main ascending projections from dorsal horn neurons are directed toward the thalamus and the midbrain periaqueductal grey region (PAG). The thalamus is notably an essential relay and processing point of nociceptive inputs from the spinal cord to the cerebral cortex. The thalamus shows an intense labeling for almost all mGluRs, as revealed by in situ hybridization [78]. However, the potential role of group III mGluRs in the processing of sensory information in the thalamus remains to be clarified.

The amygdala is an important center for the processing of the emotional component associated with pain [79]. 'In arthritic rats, the group III agonist, L-AP4, inhibits the pain-related synaptic plasticity of the central nucleus of the amygdala (CeA), the output structure that projects to the hypothalamus and several brainstem regions such the PAG [80].

An important pain descending pathway originates within PAG and projects to the spinal dorsal horn via the rostral ventromedial medulla (RVM) [81]. Activation of this descending system elicits analgesia by inhibiting ascending nociceptive transmission at the spinal cord level. Stimulation of group III mGluRs in the PAG facilitates pain behavior in naïve animals and in the formalin test $[26,82]$.

So far, preclinical studies aimed to decipher the individual roles of group III mGluRs in the supraspinal structures involved in pain processing have mainly focused on the opposing effects of mGlu7 and mGlu8 (See $[13,83]$ for extensive and recent reviews on the subject). Indeed, while systemic administration of the mGlu7 PAM AMN082 decreases allodynia in an animal model of neuropathic pain [54], and systemic administration of the mGlu8 selective agonist (S)-3,4-DCPG reduces hyperalgesia induced by inflammatory or neuropathic pain model [34], opposing effects are observed these two receptors are observed at the level of PAG, RVM or amygdala. Blockade of mGlu7 by microinjection of the selective mGlu7 NAM MMPIP in the PAG reduces the pain related behaviors in formalin and neuropathic pain models and differentially modulates RVM ON and OFF cell activity [58], while its activation increases pain [33]. On the other hand, injection of the mGlu8 selective 
agonist (S)-3,4-DCPG into the PAG alleviates pain in mice models of inflammatory and neuropathic pain $[33,34]$. Moreover, activation of mGlu8 in the dorsal striatum by local injection of (S)-3,4-DCPG or AZ12216052, a selective mGlu8 PAM, inhibits ON cells and stimulates OFF cells within RVM and reduces thermoceptive responses and mechanical allodynia in neuropathic pain [37]. At the level of the amygdala, activation of mGlu7 in the CeA by AMN082 aggravates sensory and emotional components in a model of arthritic inflammatory pain, while mGlu8 activation by (S)-3,4-DCPG reduces them $[84,85]$. Interestingly, the opposite effects of mGlu7 and mGlu8 activation might be correlated with their respective autoreceptor or heteroreceptor role on glutamatergic or GABAergic terminals in PAG [33] and their segregation in different neuronal pathways within the amygdala $[68,86]$.

\section{CONCLUSION}

Taken together, these data suggest that group III mGluRs could be interesting therapeutic targets to alleviate chronic pain. Indeed, these receptors seem to be dedicated to the modulation of pain hypersensitivity and cognitive and emotional impairments observed in preclinical models of chronic pain. However, with the help of the novel selective pharmacological tools, further studies will be needed in order to clarify the precise roles of each subtype and their therapeutic potential. 


\section{ACKNOWLEDGEMENTS}

This work was supported by grants from the Fondation Recherche Médicale (FRM team DEQ20130326522), the Fundació La Marató de TV3 (Ref 110232), Eranet Neuron and the Agence Nationale de la Recherche (ANR-12-NEUR-0003; ANR-13-BSV1-006).FA and CG were supported by the Centre National de la Recherche Scientifique (CNRS).

\section{CONFLICT OF INTEREST}

Nothing declared

\section{ABBREVIATIONS}

ACPT, (1S,3R,4S)-1-amino-cyclopentane-1,3,4-tricarboxylic acid; AP4, 2-amino-4-phosphonobutyric acid; DCPG, (S)-3,4-dicarboxyphenylglycine; CPPG, $\alpha$-cyclopropyl-4-phosphonophenylglycine; LY341495 (2S)-2-amino-2-[(1S,2S)-2-carboxycycloprop-1-yl]-3-(xanth-9-yl) propanoic acid; LSP4-2022 2-amino-4-(((4-(carboxymethoxy)phenyl)(hydroxy)methyl)(hydroxy)phosphoryl)butanoic acid; MAP4, (S)-2-amino-2-methyl-4-phosphonobutanoic acid; MMPIP, 6-(4-methoxyphenyl)-5-methyl-3-pyridin4-ylisoxazolo[4,5-c]pyridin-4(5H)-one; SOP, serine-O-phosphate; MSOP, $\alpha$-methylserine-Ophosphate; PHCCC, N-Phenyl-7-(hydroxyimino)cyclopropa[b]chromen-1a-carboxamide 


\section{REFERENCES}

1. Bouhassira D, Lanteri-Minet M, Attal N, Laurent B, Touboul C: Prevalence of chronic pain with neuropathic characteristics in the general population. Pain (2008) 136:380-387.

2. Ospina M, Harstall C: Prevalence of Chronic Pain: an Overview. In Health Technology Assessment. Edited by Research AHFfM. Edmonton, AB; 2002.

3. Verhaak PF, Kerssens JJ, Dekker J, Sorbi MJ, Bensing JM: Prevalence of chronic benign pain disorder among adults: a review of the literature. Pain (1998) 77:231-239.

4. Breivik H, Collett B, Ventafridda V, Cohen R, Gallacher D: Survey of chronic pain in Europe: prevalence, impact on daily life, and treatment. Eur J Pain (2006) 10:287-333.

5. Finnerup NB, Sindrup SH, Jensen TS: The evidence for pharmacological treatment of neuropathic pain. Pain (2010) 150:573-581.

6. Nightingale S: The neuropathic pain market. Nature reviews Drug discovery (2012) 11:101102.

7. Latremoliere A, Woolf $\mathrm{CJ}$ : Central sensitization: a generator of pain hypersensitivity by central neural plasticity. J Pain (2009) 10:895-926.

8. Kniazeff J, Prezeau L, Rondard P, Pin JP, Goudet C: Dimers and beyond: The functional puzzles of class C GPCRs. Pharmacology \& therapeutics (2011) 130:9-25.

9. Doumazane E, Scholler P, Zwier JM, Trinquet E, Rondard P, Pin JP: A new approach to analyze cell surface protein complexes reveals specific heterodimeric metabotropic glutamate receptors. FASEB J. (2011) 25:66-77.

10. Yin S, Noetzel MJ, Johnson KA, Zamorano R, Jalan-Sakrikar N, Gregory KJ, Conn PJ, Niswender $\mathrm{CM}$ : Selective actions of novel allosteric modulators reveal functional heteromers of metabotropic glutamate receptors in the CNS. J Neurosci (2014) 34:79-94.

11. Chiechio S, Nicoletti F: Metabotropic glutamate receptors and the control of chronic pain. Curr Opin Pharmacol (2012) 12(1):28-34.

12. Montana MC, Gereau RW: Metabotropic glutamate receptors as targets for analgesia: antagonism, activation, and allosteric modulation. Curr Pharm Biotechnol (2011) 12(10):1681-1688.

13. Palazzo E, Marabese I, de Novellis V, Rossi F, Maione S: Supraspinal metabotropic glutamate receptors: a target for pain relief and beyond. Eur J Neurosci (2014) 39:444-454.

14. Fisher K, Coderre TJ: The contribution of metabotropic glutamate receptors (mGluRs) to formalin-induced nociception. Pain (1996) 68:255-263.

15. Fisher K, Lefebvre C, Coderre TJ: Antinociceptive effects following intrathecal pretreatment with selective metabotropic glutamate receptor compounds in a rat model of neuropathic pain. Pharmacol Biochem Behav (2002) 73:411-418.

16. Chen SR, Pan HL: Distinct roles of group III metabotropic glutamate receptors in control of nociception and dorsal horn neurons in normal and nerve-injured Rats. J Pharmacol Exp Ther (2005) 312:120-126. 
**Demonstration that activation of spinal group III mGluRs by the group III agonist L-AP4 attenuates allodynia and inhibits the evoked responses of ascending dorsal horn neurons in nerve-injured rats while it produces no effect on nociception or spinal transmission in naive rats.

17. Jung CY, Choi HS, Ju JS, Park HS, Kwon TG, Bae YC, Ahn DK: Central metabotropic glutamate receptors differentially participate in interleukin-1beta-induced mechanical allodynia in the orofacial area of conscious rats. J Pain (2006) 7:747-756.

18. Lee MK, Choi BY, Yang GY, Jeon HJ, Kyung HM, Kwon OW, Park HS, Bae YC, Mokha SS, Ahn DK: Low doses of cannabinoids enhance the antinociceptive effects of intracisternally administered mGluRs groups II and III agonists in formalin-induced TMJ nociception in rats. Pain (2008) 139:367-375.

19. Zhang HM, Chen SR, Pan HL: Effects of activation of group III metabotropic glutamate receptors on spinal synaptic transmission in a rat model of neuropathic pain. Neuroscience (2009) 158:875-884.

20. Chen HS, Qu F, He X, Kang SM, Liao D, Lu SJ: Differential roles of peripheral metabotropic glutamate receptors in bee venom-induced nociception and inflammation in conscious rats. J Pain (2010) 11:321-329.

21. Dolan S, Gunn MD, Crossan C, Nolan AM: Activation of metabotropic glutamate receptor 7 in spinal cord inhibits pain and hyperalgesia in a novel formalin model in sheep. Behav Pharmacol (2011) 22:582-588.

22. Carlton SM, Zhou S, Govea R, Du J: Group II/III metabotropic glutamate receptors exert endogenous activity-dependent modulation of TRPV1 receptors on peripheral nociceptors. J Neurosci (2011) 31(36):12727-12737.

**This study shows that group II/III mGluRs are endogenously activated after high-frequency and/or prolonged nociceptor stimulation, modulating nociceptor function through TRPV1 and reducing pain transmission to the CNS.

23. Liu XH, Han M, Zhu JX, Sun N, Tang JS, Huo FQ, Li J, Xu FY, Du JQ: Metabotropic glutamate subtype 7 and 8 receptors oppositely modulate cardiac nociception in the rat nucleus tractus solitarius. Neuroscience (2012) 220:322-329.

24. Lee KS, Park EH, Cho HY, Kim YI, Han HC: Peripheral group II and III metabotropic glutamate receptors in the knee joint attenuate carrageenan-induced nociceptive behavior in rats. Neurosci Lett (2013) 542:21-25.

25. Maione S, Marabese I, Leyva J, Palazzo E, de Novellis V, Rossi F: Characterisation of mGluRs which modulate nociception in the PAG of the mouse. Neuropharmacology (1998) 37:14751483.

26. Maione S, Oliva P, Marabese I, Palazzo E, Rossi F, Berrino L, Filippelli A: Periaqueductal gray matter metabotropic glutamate receptors modulate formalin-induced nociception. Pain (2000) 85:183-189.

27. Acher F, Tellier F, Brabet I, Fagni L, Azerad R, Pin J-P: Synthesis and pharmacological characterization of aminocyclopentane tricarboxylic acids (ACPT): new tools to discriminate between metabotropic glutamate receptor subtypes. J Med Chem (1997) 40:3119-3129. 
28. Palucha-Poniewiera A, Klodzinska A, Stachowicz K, Tokarski K, Hess G, Schann S, Frauli M, Neuville $P$, Pilc A: Peripheral administration of group III mGlu receptor agonist ACPT-I exerts potential antipsychotic effects in rodents. Neuropharmacology (2008) 55:517-524.

29. Goudet C, Chapuy E, Alloui A, Acher F, Pin JP, Eschalier A: Group III metabotropic glutamate receptors inhibit hyperalgesia in animal models of inflammation and neuropathic pain. Pain (2008) 137:112-124.

30. Lee HG, Park SK, Yoon MH: Potentiation of morphine antiallodynic efficacy by ACPT-III, a group III metabotropic glutamate receptor agonist, in rat spinal nerve ligation-induced neuropathic pain. Pharmacol Biochem Behav (2010) 96:108-113.

31. Thomas NK, Wright RA, Howson PA, Kingston AE, Schoepp DD, Jane DE: (S)-3,4-DCPG, a potent and selective $\mathrm{mGlu8a}$ receptor agonist, activates metabotropic glutamate receptors on primary afferent terminals in the neonatal rat spinal cord. Neuropharmacology (2001) 40:311-318.

*This study describes the characterization of (S)-3,4-DCPG, a potent and selective mGlu8 agonist.

32. Goudet C, Vilar B, Courtiol T, Deltheil T, Bessiron T, Brabet I, Oueslati N, Rigault D, Bertrand $\mathrm{HO}$, McLean $\mathrm{H}$, Daniel $\mathrm{H}$ et al: A novel selective metabotropic glutamate receptor 4 agonist reveals new possibilities for developing subtype selective ligands with therapeutic potential. FASEB J (2012) 26:1682-1693.

33. Marabese I, Rossi F, Palazzo E, de Novellis V, Starowicz K, Cristino L, Vita D, Gatta L, Guida F, Di Marzo V, Maione S: Periaqueductal gray metabotropic glutamate receptor subtype 7 and 8 mediate opposite effects on amino acid release, rostral ventromedial medulla cell activities, and thermal nociception. J Neurophysiol (2007) 98:43-53.

34. Marabese I, de Novellis V, Palazzo E, Scafuro MA, Vita D, Rossi F, Maione S: Effects of (S)-3,4DCPG, an mGlu8 receptor agonist, on inflammatory and neuropathic pain in mice. Neuropharmacology (2007) 52:253-262.

35. Ren W, Palazzo E, Maione S, Neugebauer V: Differential effects of mGluR7 and mGluR8 activation on pain-related synaptic activity in the amygdala. Neuropharmacology (2011) 61:1334-1344.

36. Vilar B, Busserolles J, Ling B, Laffray S, Ulmann L, Malhaire F, Chapuy E, Aissouni Y, Etienne M, Bourinet E, Acher F et al: Alleviating pain hypersensitivity through activation of type 4 metabotropic glutamate receptor. The Journal of neuroscience : the official journal of the Society for Neuroscience (2013) 33:18951-18965.

** This study describes the location of mGlu4 on unmyelinated C-fibers and spinal neurons terminals in the inner lamina II of the spinal cord, their ability to modulate neurotransmission in the dorsal horn and to alleviate pain hypersensitivity in animal models of inflammatory and neuropathic pain. It also describes the pain-related behavior of mGlu4KO mice

37. Rossi F, Marabese I, De Chiaro M, Boccella S, Luongo L, Guida F, De Gregorio D, Giordano C, de Novellis V, Palazzo E, Maione S: Dorsal striatum metabotropic glutamate receptor 8 affects nocifensive responses and rostral ventromedial medulla cell activity in neuropathic pain conditions. J Neurophysiol (2014) 111:2196-2209. 
38. Mercier MS, Lodge D, Fang G, Nicolas CS, Collett VJ, Jane DE, Collingridge GL, Bortolotto ZA: Characterisation of an mGlu 8 receptor-selective agonist and antagonist in the lateral and medial perforant path inputs to the dentate gyrus. Neuropharmacology (2013) 67:294-303.

39. Zhou HY, Zhang HM, Chen SR, Pan HL: Increased nociceptive input rapidly modulates spinal GABAergic transmission through endogenously released glutamate. J Neurophysiol (2007) 97:871-882.

40. Kingston AE, Ornstein PL, Wright RA, Johnson BG, Mayne NG, Burnett JP, Belagaje R, Wu S, Schoepp DD: LY341495 is a nanomolar potent and selective antagonist of group II metabotropic glutamate receptors. Neuropharmacology (1998) 37:1-12.

41. Liang YC, Huang CC, Hsu KS: Characterization of long-term potentiation of primary afferent transmission at trigeminal synapses of juvenile rats: essential role of subtype 5 metabotropic glutamate receptors. Pain (2005) 114:417-428.

42. Fundytus ME, Ritchie J, Coderre TJ: Attenuation of morphine withdrawal symptoms by subtype-selective metabotropic glutamate receptor antagonists. Br J Pharmacol (1997) 120:1015-1020.

43. Palazzo E, Marabese I, de Novellis V, Oliva P, Rossi F, Berrino L, Maione S: Metabotropic and NMDA glutamate receptors participate in the cannabinoid-induced antinociception. Neuropharmacology (2001) 40:319-326.

44. Palazzo E, de Novellis V, Marabese I, Cuomo D, Rossi F, Berrino L, Maione S: Interaction between vanilloid and glutamate receptors in the central modulation of nociception. European journal of pharmacology (2002) 439:69-75.

45. Jin $\mathrm{YH}$, Takemura $\mathrm{M}$, Furuyama $\mathrm{A}$, Yonehara $\mathrm{N}$ : Peripheral glutamate receptors are required for hyperalgesia induced by capsaicin. Pain Res Treat (2012) 2012:915706.

46. Dolan S, Gunn MD, Biddlestone L, Nolan AM: The selective metabotropic glutamate receptor 7 allosteric agonist AMN082 inhibits inflammatory pain-induced and incisioninduced hypersensitivity in rat. Behav Pharmacol (2009) 20:596-604.

47. Maj M, Bruno V, Dragic Z, Yamamoto R, Battaglia G, Inderbitzin W, Stoehr N, Stein T, Gasparini F, Vranesic I, Kuhn R et al: (-)-PHCCC, a positive allosteric modulator of mGluR4: characterization, mechanism of action, and neuroprotection. Neuropharmacology (2003) 45:895-906.

48. Marino MJ, Williams DL, Jr., O'Brien JA, Valenti O, McDonald TP, Clements MK, Wang R, DiLella AG, Hess JF, Kinney GG, Conn PJ: Allosteric modulation of group III metabotropic glutamate receptor 4: a potential approach to Parkinson's disease treatment. Proc Natl Acad Sci U S A (2003) 100:13668-13673.

49. Niswender CM, Johnson KA, Weaver CD, Jones CK, Xiang Z, Luo Q, Rodriguez AL, Marlo JE, de Paulis T, Thompson AD, Days EL et al: Discovery, characterization, and antiparkinsonian effect of novel positive allosteric modulators of metabotropic glutamate receptor 4 . $\mathrm{Mol}$ pharmacol (2008) 74:1345-1358. 
50. Celanire S, Campo B: Recent advances in the drug discovery of metabotropic glutamate receptor $\mathbf{4}$ (mGluR4) activators for the treatment of CNS and non-CNS disorders. Expert Opin Drug Discov (2012) 7:261-280.

51. Duvoisin RM, Pfankuch T, Wilson JM, Grabell J, Chhajlani V, Brown DG, Johnson E, Raber J: Acute pharmacological modulation of mGluR8 reduces measures of anxiety. Behavioural brain research (2010) 212:168-173.

52. Duvoisin RM, Villasana L, Davis MJ, Winder DG, Raber J: Opposing roles of mGluR8 in measures of anxiety involving non-social and social challenges. Behav Brain Res (2011) 221:50-54.

53. Mitsukawa K, Yamamoto R, Ofner S, Nozulak J, Pescott O, Lukic S, Stoehr N, Mombereau C, Kuhn $\mathrm{R}$, McAllister $\mathrm{KH}$, van der Putten $\mathrm{H}$ et al: A selective metabotropic glutamate receptor 7 agonist: activation of receptor signaling via an allosteric site modulates stress parameters in vivo. Proc Natl Acad Sci USA (2005) 102:18712-18717.

54. Osikowicz M, Mika J, Makuch W, Przewlocka B: Glutamate receptor ligands attenuate allodynia and hyperalgesia and potentiate morphine effects in a mouse model of neuropathic pain. Pain (2008) 139:117-126.

55. Wang $\mathrm{H}$, Jiang $\mathrm{W}$, Yang R, Li Y: Spinal metabotropic glutamate receptor $\mathbf{4}$ is involved in neuropathic pain. Neuroreport (2011) 22(5):244-248.

56. Sukoff Rizzo SJ, Leonard SK, Gilbert A, Dollings P, Smith DL, Zhang MY, Di L, Platt BJ, Neal S, Dwyer JM, Bender CN et al: The metabotropic glutamate receptor 7 allosteric modulator AMN082: a monoaminergic agent in disguise? J Pharmacol Exp Ther (2011) 338(1):345-352.

*The orally active and brain penetrant mGlu7 PAM AMN082 is a very useful ligand to investigate the function receptor. However, this study clearly shows that this molecule is rapidly metabolized in vivo $(\mathrm{t} 1 / 2<1 \mathrm{~min})$ and that its major metabolite is a potent inhibitor of monoamine transporters. This suggests that in vivo activity of AMN082 may involve other targets than mGlu7.

57. Suzuki G, Tsukamoto N, Fushiki H, Kawagishi A, Nakamura M, Kurihara H, Mitsuya M, Ohkubo $\mathrm{M}$, Ohta $\mathrm{H}$ : In vitro pharmacological characterization of novel isoxazolopyridone derivatives as allosteric metabotropic glutamate receptor 7 antagonists. J Pharmacol Exp Ther (2007) 323:147-156.

58. Palazzo E, Marabese I, Luongo L, Boccella S, Bellini G, Giordano ME, Rossi F, Scafuro M, Novellis $V$, Maione $S$ : Effects of a metabotropic glutamate receptor subtype 7 negative allosteric modulator in the periaqueductal grey on pain responses and rostral ventromedial medulla cell activity in rat. Molecular pain (2013) 9:44.

59. Niswender CM, Johnson KA, Miller NR, Ayala JE, Luo Q, Williams R, Saleh S, Orton D, Weaver $C D$, Conn PJ: Context-dependent pharmacology exhibited by negative allosteric modulators of metabotropic glutamate receptor 7. Mol Pharmacol (2010) 77:459-468.

60. Kalinichev M, Rouillier M, Girard F, Royer-Urios I, Bournique B, Finn T, Charvin D, Campo B, Le Poul E, Mutel V, Poli S et al: ADX71743, a potent and selective negative allosteric modulator of metabotropic glutamate receptor 7 (mGlu7): in vitro and in vivo characterization. J Pharmacol Exp Ther (2013) 344:624-636. 
*In this study, the authors describe a very complete characterization of a potent, brain penetrant and selective mGlu7 NAM ADX71743 both in vitro and in vivo in many behavioural models.

61. Gee CE, Peterlik D, Neuhauser C, Bouhelal R, Kaupmann K, Laue G, Uschold-Schmidt N, Feuerbach D, Zimmermann K, Ofner S, Cryan JF et al: Blocking metabotropic glutamate receptor subtype 7 (mGlu7) via the Venus flytrap domain (VFTD) inhibits amygdala plasticity, stress, and anxiety-related behavior. J Biol Chem (2014) 289:10975-10987.

* This study describes XAP044, a selective and brain penetrant mGlu7 NAM with anti-stress, antidepressant- and anxiolytic-like efficacy in vivo, able to modulate synaptic plasticity within amygdala and which likely targets an allosteric pocket located within the extracellular domain of the receptor contrary to other mGluRs NAMs described so far.

62. Pekhletski R, Gerlai R, Overstreet LS, Huang XP, Agopyan N, Slater NT, Abramow-Newerly W, Roder JC, Hampson DR: Impaired cerebellar synaptic plasticity and motor performance in mice lacking the mGluR4 subtype of metabotropic glutamate receptor. J Neurosci (1996) 16:6364-6373.

63. Gerlai R, Roder JC, Hampson DR: Altered spatial learning and memory in mice lacking the mGluR4 subtype of metabotropic glutamate receptor. Behav Neurosci (1998) 112:525-532.

64. Sansig G, Bushell TJ, Clarke VR, Rozov A, Burnashev N, Portet C, Gasparini F, Schmutz M, Klebs K, Shigemoto R, Flor PJ et al: Increased seizure susceptibility in mice lacking metabotropic glutamate receptor 7. J Neurosci (2001) 21:8734-8745.

65. Cryan JF, Kelly PH, Neijt HC, Sansig G, Flor PJ, van Der Putten H: Antidepressant and anxiolytic-like effects in mice lacking the group III metabotropic glutamate receptor mGluR7. Eur J Neurosci (2003) 17:2409-2417.

66. Linden AM, Johnson BG, Peters SC, Shannon HE, Tian M, Wang Y, Yu JL, Koster A, Baez M, Schoepp DD: Increased anxiety-related behavior in mice deficient for metabotropic glutamate 8 (mGlu8) receptor. Neuropharmacology (2002) 43:251-259.

67. Duvoisin RM, Zhang C, Pfankuch TF, O'Connor H, Gayet-Primo J, Quraishi S, Raber J: Increased measures of anxiety and weight gain in mice lacking the group III metabotropic glutamate receptor mGluR8. Eur J Neurosci (2005) 22:425-436.

68. Fendt M, Imobersteg S, Peterlik D, Chaperon F, Mattes C, Wittmann C, Olpe HR, Mosbacher J, Vranesic I, van der Putten $\mathrm{H}$, McAllister KH et al: Differential roles of $\mathrm{mGlu}(7)$ and $\mathrm{mGlu}(8)$ in amygdala-dependent behavior and physiology. Neuropharmacology (2013) 72:215-223.

* Combining pharmacological and electrophysiological approaches with mGlu7 and mGlu8 $\mathrm{KO}$ mice, the authors investigated the roles of mGlu7 and mGlu8 in amygdala-dependent behavior and synaptic plasticity. It revealed the different roles for mGlu7 and mGlu8 in amygdala synaptic transmission, fear learning and its expression.

69. Govea RM, Zhou S, Carlton SM: Group III metabotropic glutamate receptors and transient receptor potential vanilloid 1 co-localize and interact on nociceptors. Neuroscience (2012) 217:130-139.

70. Todd AJ: Neuronal circuitry for pain processing in the dorsal horn. Nature reviews Neuroscience (2010) 11:823-836.

71. Azkue JJ, Murga M, Fernandez-Capetillo O, Mateos JM, Elezgarai I, Benitez R, Osorio A, Diez J, Puente N, Bilbao A, Bidaurrazaga A et al: Immunoreactivity for the group III metabotropic 
glutamate receptor subtype mGluR4a in the superficial laminae of the rat spinal dorsal horn. J Comp Neurol (2001) 430:448-457.

72. Ohishi H, Akazawa C, Shigemoto R, Nakanishi S, Mizuno N: Distributions of the mRNAs for L2-amino-4-phosphonobutyrate-sensitive metabotropic glutamate receptors, mGluR4 and mGluR7, in the rat brain. J Comp Neurol (1995) 360:555-570.

73. Ohishi H, Nomura S, Ding YQ, Shigemoto R, Wada E, Kinoshita A, Li JL, Neki A, Nakanishi S, Mizuno N: Presynaptic localization of a metabotropic glutamate receptor, $\mathrm{mGluR7}$, in the primary afferent neurons: an immunohistochemical study in the rat. Neurosci Lett (1995) 202:85-88.

74. Carlton SM, Hargett GL: Colocalization of metabotropic glutamate receptors in rat dorsal root ganglion cells. J Comp Neurol (2007) 501:780-789.

75. Valerio A, Paterlini M, Boifava M, Memo M, Spano P: Metabotropic glutamate receptor mRNA expression in rat spinal cord. Neuroreport (1997) 8:2695-2699.

76. Duvoisin RM, Zhang C, Ramonell K: A novel metabotropic glutamate receptor expressed in the retina and olfactory bulb. J Neurosci (1995) 15:3075-3083.

77. Mills CD, Johnson KM, Hulsebosch CE: Role of group II and group III metabotropic glutamate receptors in spinal cord injury. Exp Neurol (2002) 173:153-167.

78. Lourenco Neto F, Schadrack J, Berthele A, Zieglgansberger W, Tolle TR, Castro-Lopes JM: Differential distribution of metabotropic glutamate receptor subtype mRNAs in the thalamus of the rat. Brain research (2000) 854:93-105.

79. Neugebauer V: Chapter 11 Subcortical processing of nociceptive information: basal ganglia and amygdala. Handb Clin Neurol (2006) 81:141-158.

80. Han JS, Bird GC, Neugebauer V: Enhanced group III mGluR-mediated inhibition of painrelated synaptic plasticity in the amygdala. Neuropharmacology (2004) 46:918-926.

81. Millan MJ: Descending control of pain. Prog Neurobiol (2002) 66:355-474.

82. Maione S, Palazzo E, de Novellis V, Stella L, Leyva J, Rossi F: Metabotropic glutamate receptors modulate serotonin release in the rat periaqueductal gray matter. Naunyn Schmiedebergs Arch Pharmacol (1998) 358:411-417.

83. Palazzo E, de Novellis V, Rossi F, Maione S: Supraspinal metabotropic glutamate receptor subtype 8: a switch to turn off pain. Amino Acids (2014) 46:1441-1448.

84. Palazzo E, Fu Y, Ji G, Maione S, Neugebauer V: Group III mGluR7 and mGluR8 in the amygdala differentially modulate nocifensive and affective pain behaviors. Neuropharmacology (2008) 55:537-545.

85. Palazzo E, Marabese I, Soukupova M, Luongo L, Boccella S, Giordano C, de Novellis V, Rossi F, Maione $S$ : Metabotropic glutamate receptor subtype 8 in the amygdala modulates thermal threshold, neurotransmitter release, and rostral ventromedial medulla cell activity in inflammatory pain. J Neurosci (2011) 31:4687-4697.

86. Dobi A, Sartori SB, Busti D, Van der Putten $H$, Singewald N, Shigemoto R, Ferraguti F: Neural substrates for the distinct effects of presynaptic group III metabotropic glutamate 
receptors on extinction of contextual fear conditioning in mice. Neuropharmacology (2013) 66:274-289.

87. Pin JP, De Colle C, Bessis AS, Acher F: New perspectives for the development of selective metabotropic glutamate receptor ligands. Eur J Pharmacol (1999) 375:277-294.

88. Schoepp DD, Jane DE, Monn JA: Pharmacological agents acting at subtypes of metabotropic glutamate receptors. Neuropharmacology (1999) 38:1431-1476. 
Table 1. Potencies of ligands used to study group III mGluR function in preclinical models of pain.

\begin{tabular}{|c|c|c|c|c|c|}
\hline & mGlu4 & mGlu6 & mGlu7 & mGlu8 & Ligand issues \\
\hline \multicolumn{6}{|l|}{ Agonist (EC50 $\mu \mathrm{M})$} \\
\hline Glu $(* *)$ & 3.4 & 24.2 & $>500$ & 2.4 & \\
\hline L-AP4 * & 0.2 & 1 & 249 & 0.3 & not selective among mGlu4/6/8 [87] \\
\hline L-SOP [88] [87] & $1-4$ & 3 & $160-1200$ & 2 & not selective among mGlu4/6/8 [87] \\
\hline ACPT-I $(* *)$ & 1.7 & 10.6 & 280 & 5 & not selective among mGlu4/6/8 [29] \\
\hline$(S)-D C P G[31](*)$ & $8.8-3.2$ & $3.6-3,2$ & $>100$ & $0.03-0.04$ & $\begin{array}{l}\text { not selective at concentration }>1 \mu \mathrm{M} \\
\text { [38] }\end{array}$ \\
\hline LSP4-2022 $(*)[32]$ & 0.1 & 4.4 & 11.6 & 29.2 & rapid clearance [32] \\
\hline \multicolumn{6}{|c|}{ Antagonists (IC50 $\mu \mathrm{M}$ ) } \\
\hline LY341495 [88] & $6.8-9.7$ & $1.1-1.8$ & 0.99 & 0.17 & not selective among mGluRs [87] \\
\hline MAP4 [88] [87] & $90-190$ & & & $25-105$ & weak potency [87] \\
\hline CPPG [88] & 12 & 4 & 17 & 11 & weak potency [88] \\
\hline \multicolumn{6}{|l|}{ PAM (EC50 $\mu \mathrm{M})$} \\
\hline $\operatorname{PHCCC}(*)$ & 5.1 & & & & $\begin{array}{l}\text { lack of selectivity, relatively low } \\
\text { potency and poor solubility [49] }\end{array}$ \\
\hline VU155041 (*) & 1.0 & & & & poor brain exposure [50] \\
\hline AZ12216052 [51] & 1.0 & & & & $\begin{array}{l}\text { lack of selectivity described in a study } \\
\text { [52] }\end{array}$ \\
\hline AMN082 [53] & & & & & metabolic instability [56] (55) \\
\hline \multicolumn{6}{|l|}{ NAM (IC50 $\mu \mathrm{M})$} \\
\hline MMPIP [57] & & & 0.22 & & context dependent inhibitor [59] \\
\hline ADX71743[60] & & & 0.06 & & poor solubility [60] \\
\hline XAP044 [61] & & & 3.5 & & recent disclosure, no hindsight [61] \\
\hline
\end{tabular}

EC50 or IC50 values are taken from the literature, except for * and ${ }^{* *}$ which stands for EC50 values determined either by intracellular Ca release measurement* or inositol phosphate accumulation** on rat clone of group III mGluRs transiently expressed in HEK293 cells (personal data). 
FIGURE LEGENDS

Figure 1. Localization and function of mGluRs in the pain neuraxis. The different subtypes of mGluRs are expressed all along the pain neuraxis where they modulate pain perception. Ascending pain pathway is in red and descending pathway in green. Up arrows mean that activation of a particular subtype is proalgesic while down arrows mean that activation is analgesic. PAG: Periaqueducal Gray; RVM: Rostral ventromedial medulla; DRG: Dorsal Root Ganglion.

Figure 2. Chemical structures of orthosteric and allosteric group III mGlu receptor ligands. 


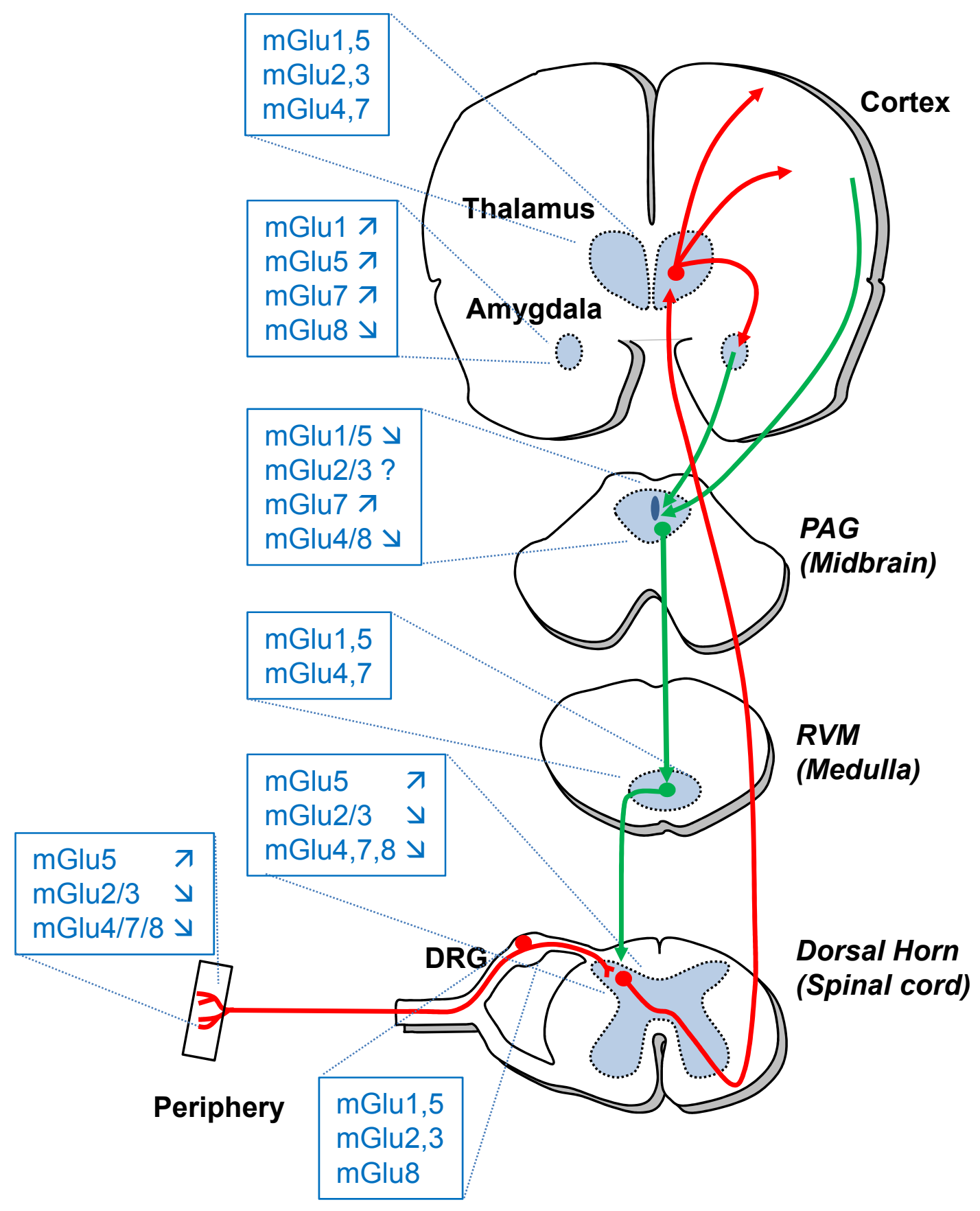

Figure 1. Localization and function of mGluRs in the pain neuraxis. 


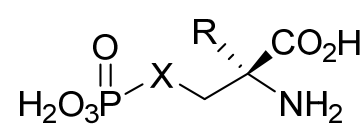

L-AP4 $\quad \mathrm{X}=\mathrm{CH} 2 \quad \mathrm{R}=\mathrm{H}$ L-SOP $X=\mathrm{O} \quad \mathrm{R}=\mathrm{H}$ MAP4 $X=\mathrm{CH} 2 \mathrm{R}=\mathrm{Me}$ MSOP $X=O \quad R=M e$

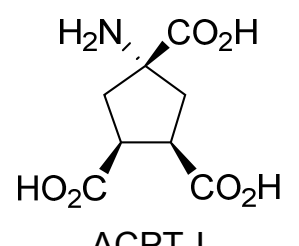

ACPT-I

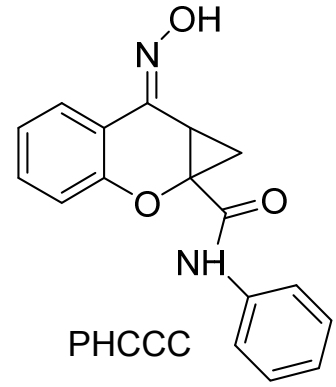

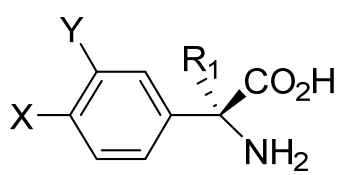

(S)-DCPG $\quad X=Y=C O 2 H$

$\mathrm{R} 1=\mathrm{H}$

CPPG $\quad \mathrm{X}=\mathrm{PO} 3 \mathrm{H} 2 \mathrm{Y}=\mathrm{H} \quad \mathrm{R} 1$ = cyclopropyl $\quad$ LY341495 R = 9'-xanthylmethyl
$\overbrace{\mathrm{H}}^{\mathrm{R}} \mathrm{K}_{\mathrm{NH}_{2}}^{\mathrm{CO}_{2} \mathrm{H}}$

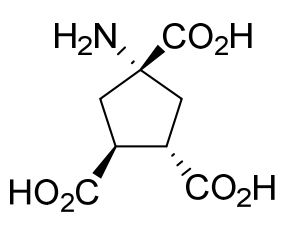

ACPT-III

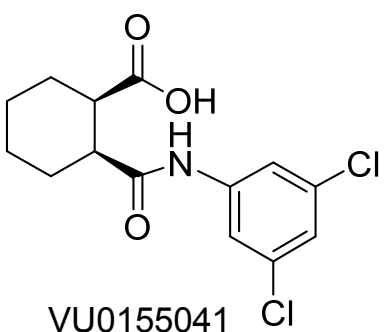

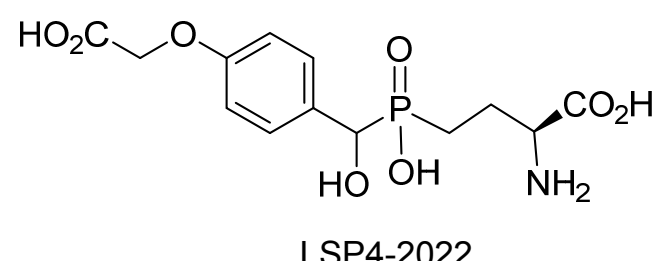

LSP4-2022

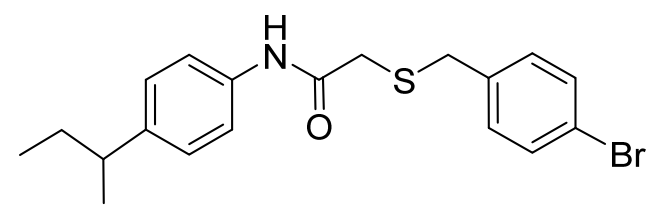

AZ12216052

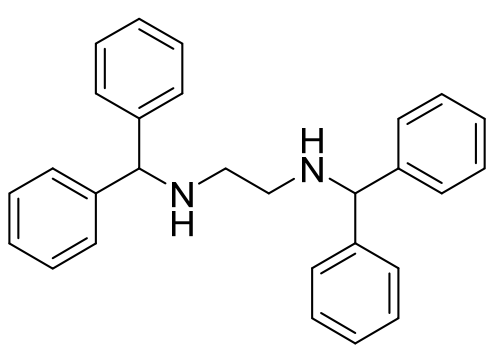

AMN082

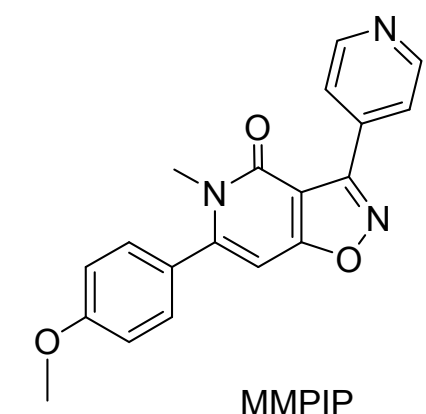

MMPIP

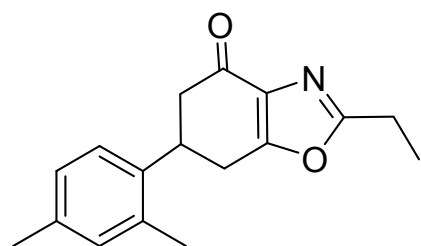

ADX71743

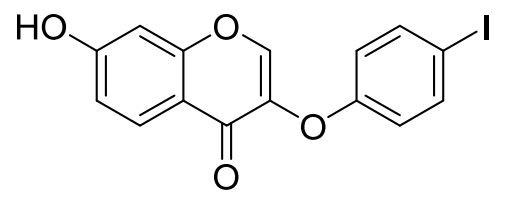

XAP044

Figure 2. Chemical structures of orthosteric and allosteric group III mGlu receptor ligands. 